\title{
Studies Concerning the Quality of Felix Soybean Breed
}

\author{
Valeria DEAC ${ }^{1}$, Ioan ROTAR ${ }^{2 *}$, Roxana VIDICAN² ${ }^{2}$ Anamaria MĂLINAŞ² \\ ${ }^{1}$ Agricultural Research Development Station Turda, Agriculturii str., no. 27, Cluj County, Romania. \\ ${ }^{2}$ Department of Plant Culture. Faculty of Agriculture, University of Agriculture Sciences and Veterinary \\ Medicine Cluj-Napoca, Romania. \\ *corresponding author: rotarioan52@yahoo.fr
}

Bulletin UASVM series Agriculture 73(2)/2016

Print ISSN 1843-5246; Electronic ISSN 1843-5386

DOI 10.15835/buasvmcn-agr: 12410

\begin{abstract}
Soy protein is the most inexpensive source of high-nutritional quality protein and therefore is the world's predominant commercially available vegetable protein. In order to keep this levels of fat and proteins at higher standards studies need to be develop in order to highlight the factors affecting soybean quality. The aim of our research was to analyse the variations in soybean protein and fat content and thru this to highlight the optimum management of nutrients for achieving high quality soy products. The experimental field was placed in the Agricultural Research Development Turda (ARDS) in 2013. The biological material consists in a genotype of soybean created at ARDS Turda - Felix variety. The experimental plots were installed after the subdivided parcel method and were fertilized with mineral and organic fertilizers in 4 different doses. In order to accomplish our goal we followed soy content in protein and fat under the influence of the inputs applied. Analysing the data recorded we observed a low influence of the experimental factors on soybean seeds content in fat substances. In the same time the protein content varies significantly under the influence of the technological inputs applied. The highest increases in protein content are achieved when organic fertilizer is applied. The results showed an interesting evolution of soybean chemical content under the influence of differentiated fertilization and also some interesting correlation between chemical content and some production indexes.
\end{abstract}

Keywords: soybean, quality, fertilization.

\section{INTRODUCTION}

Soybean crop has extended on worldwide scale mainly due to its inclusion in many foods but also due to its importance as forage crop (Dwevedi and Kayastha, 2011; De Bruin and Pedersen, 2008). Soybean seeds used in animal nutrition are a valuable forage since the entire plant can be used as green mass, hay or silage, alone or in mixture with other forage plants (Muntean et al., 2011). In the same time this plant has an outstanding economic importance due to its nutritional value and its role in vegetal oil and bio oil industries. Soybean oil has a great quality and occupies the first place in worldwide production of vegetal oils (75 - 85 \%, Adu - Dapaah et al., 2004; MoFA and CSIR, 2005; Rotar et al., 2015).
In Transylvania Plain the climate and soil condition could offer optimum condition for soybean crop but studies are still required in order to highlight the most suitable breeds for achieving both high quality and premium quality. The Agricultural Research Development Station (ARDS) Turda has a great tradition in soybean research and they have developed until present several breeds created to face different soilclimatic conditions and nutritional requirements.

The aim of our study was to analyse the reaction of a soybean breed created on ARDS Turda to different fertilization regime. We followed specifically the variations in quality as a result of the treatments applied and the correlation between some morphological indices and soybean quality. 


\section{MATERIALS AND METHODS}

The experimental was conducted in the field of Agricultural Research Development Turda (ARDS) located in Transylvania Plain, Romania in 2013 and 2014. The climate is temperate-continental with $8.9^{\circ} \mathrm{C}$ annual average temperature of the last 50 years and annual rainfalls ranging between $325 \mathrm{~mm}$ and $671 \mathrm{~mm}$. The mean monthly rainfall and temperatures that were observed during the experiment are in Fig. 1 and 2.

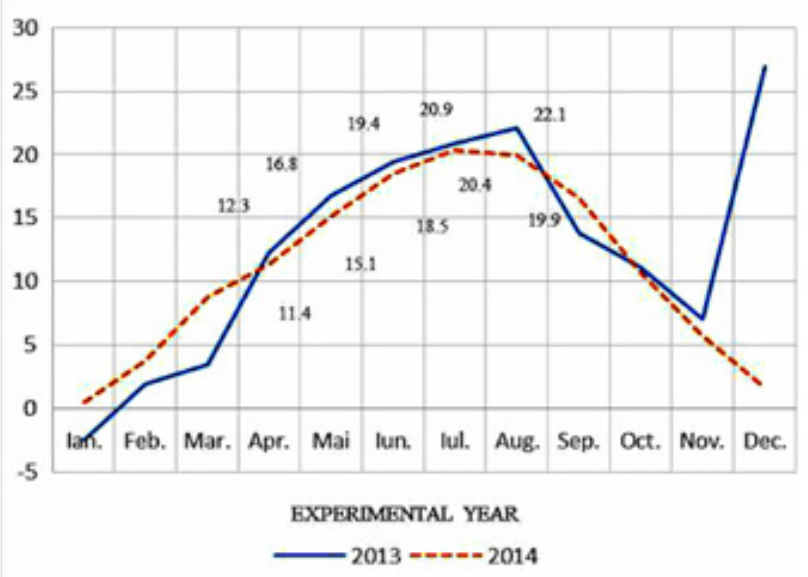

Fig. 1. Monthly average temperature recorded in 2013 and 2014

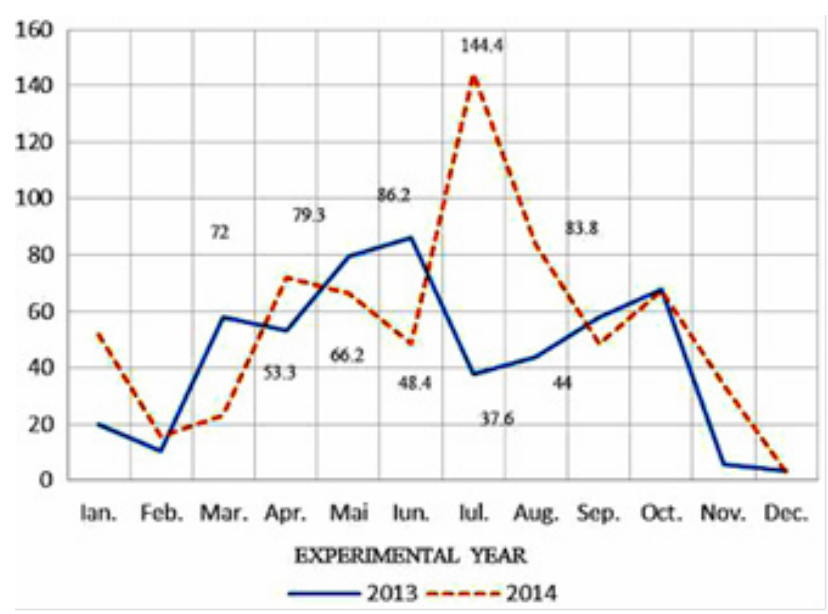

Fig. 2. Monthly amount of rainfall recorded in 2013 and 2014

The biological material consists in a genotype of soybean created at ARDS Turda - Felix variety. The cultivar is included in 00 maturity class and claims a protein content around $41.5 \%$.

The soil of the experimental area is classified as typical clay faeoziom having 3.5\% humus, more than $4.5 \mathrm{mg} \mathrm{P}_{2} \mathrm{O}_{5} / 100 \mathrm{~g}$ soil (AL) Phosphorus and more than $30 \mathrm{mg} \mathrm{K}_{2} \mathrm{O} / 100 \mathrm{~g}$ soil (AL) Potassium.

The cow wastewater (gulle) came from a cow farm located in neighbourhood of the experimental field and was applied once/year in the spring, before sowing. Chemical analysis of gulle revealed a good amount in nutrients (N-NO - 1461 ppm; N - 0,730 ppm; P - 112 ppm; K - 3438 ppm). The applied gulle rates were G1-0 t/ha gulle; G2-5 t/ ha gulle, G3-10 t/ha gulle, g4-15 t/ha gulle in 4 replications.

The mineral fertilizer came from AZOMURES Company and consists in phosphorus applied once/year. The experimental plots consisted of a control (P1, unfertilized) and 2 treatments: P2- 50 $\mathrm{kg} / \mathrm{ha}$ P205, P3- $100 \mathrm{~kg} / \mathrm{ha}$ P205.

The experimental plots were installed after the subdivided parcel method. The agricultural indexes assumed were the number of nodules at the beginning of flowering (N1), number of nodules at the end of flowering (N2) and nutritional analysis (protein (PC) and fat content (FC)).

Statistical interpretation of data recorded was performed by Statistica v 10.0.

\section{RESULTS AND DISCUSSION}

Analysing the data recorded we observed an insignificantly influence of fertilization with gulle on soybean seeds content in fat substances although fat content seems to be influenced by the climatic conditions which seemed to be more favourable in 2013 (Tab. 1). On the other hand protein content varies significantly under the influence of gulle fertilization. An increased influence was recorded also by the climatic conditions, the highest values being recorded in 2013. In which concerns the influence of gulle on protein content we observed that the highest increase was achieved on G4 in 2013.

An insignificantly influence on fat content was observed also in the case of mineral fertilization. The highest fat content was achieved in 2013 on all the experimental plot (Tab. 2). Similar reaction was observed also in the case of protein content which varies significantly under the influence of the climatic conditions the highest values being recorded in 2013. In which concerns the influence of mineral treatments on protein content we observed that the highest increase was achieved on P3 (100 kg/ha $\left.\mathrm{P}_{2} \mathrm{O}_{5}\right)$ in 2013. 
Tab. 1. Effect of gulle addition on Felix soybean

\begin{tabular}{|c|c|c|c|c|c|}
\hline $\begin{array}{c}\text { Experimental } \\
\text { year }\end{array}$ & $\begin{array}{l}\text { Experimental } \\
\text { plot }\end{array}$ & N1 & $\mathrm{N} 2$ & $\begin{array}{c}\mathrm{PC} \\
{[\%]}\end{array}$ & $\begin{array}{c}\mathrm{FC} \\
{[\%]}\end{array}$ \\
\hline \multirow{4}{*}{2013} & $\mathrm{G} 1$ & $78,11^{c t}$ & $123,66^{\mathrm{ct}}$ & $40,50^{c t}$ & $22,28^{\mathrm{ct}}$ \\
\hline & G2 & $88,22^{* * *}$ & $113,00^{\circ}$ & $41,10^{* * *}$ & $22,52^{*}$ \\
\hline & G3 & $94,67^{* * *}$ & $154,33^{* m}$ & $41,76^{*}$ & $22,46^{\circ}$ \\
\hline & G4 & 101,00 & 157,66 & $42,26^{* * *}$ & $22,47^{-}$ \\
\hline \multirow{4}{*}{2014} & G1 & $99,0^{\mathrm{ct}}$ & $87,56^{\mathrm{ct}}$ & $34,68^{c t}$ & $17,91^{\mathrm{ct}}$ \\
\hline & G2 & $122,33^{* * *}$ & $106,13^{* *+4}$ & $34,84^{*}$ & $17,91^{-}$ \\
\hline & G3 & 129,89 & 110,72 & $34,93^{* *}$ & $17,91^{\circ}$ \\
\hline & G4 & 137,56 & 113,23 & 34,97 & $17,92^{-}$ \\
\hline
\end{tabular}

Note 1: - not significant $\mathrm{p}<0.05^{*}$ $\mathrm{p}<0.01^{* *}$ $\mathrm{p}<0.001$

Note 2: N1- number of nodules at the beginning of flowering; N2- number of nodules at the end of flowering; PC -protein content; FC- fat content; P1-control, unfertilized, P2- fertilized with $50 \mathrm{~kg} / \mathrm{ha}$ P205; P3- fertilized with $100 \mathrm{~kg} / \mathrm{ha}$ P2O5; G1-control, unfertilized; G2- fertilized with 5 t/ha gulle; G3- fertilized with 10 t/ha gulle; G4- fertilized with 15 t/ha gulle.

Tab. 2. Effect of phosphorus addition on Felix soybean

\begin{tabular}{|c|c|c|c|c|c|}
\hline $\begin{array}{c}\text { Experimental } \\
\text { year }\end{array}$ & $\begin{array}{l}\text { Experimental } \\
\text { plot }\end{array}$ & N1 & N2 & $\begin{array}{c}\mathrm{PC} \\
{[\%]}\end{array}$ & $\begin{array}{c}\mathrm{FC} \\
{[\%]}\end{array}$ \\
\hline \multirow{3}{*}{2013} & $\mathrm{P} 1$ & $84,08^{\mathrm{ct}}$ & $123,66^{\mathrm{ct}}$ & $41,25^{\mathrm{ct}}$ & $22,33^{\mathrm{ct}}$ \\
\hline & P2 & 91,58 & $123,00^{-}$ & $41,37^{-}$ & $22,38^{-}$ \\
\hline & P3 & 95,83 & $125,33^{*}$ & 41,59 & 22,58 \\
\hline \multirow{3}{*}{2014} & $\mathrm{P} 1$ & $115,42^{\text {ct }}$ & $93,22^{c t}$ & $34,81^{\mathrm{ct}}$ & $17,93^{\mathrm{ct}}$ \\
\hline & $\mathrm{P} 2$ & 123,50 & 119,28 & $34,90^{-}$ & $17,92^{-}$ \\
\hline & P3 & 127,67 & $100,73^{*}$ & $34,71^{-}$ & $17,90^{\circ}$ \\
\hline
\end{tabular}

\section{Note 1: - not significant $\quad \mathrm{p}<0.05^{*} \quad \mathrm{p}<0.01^{* *} \quad \mathrm{p}<0.001 \quad * * *$}

Note 2: N1- number of nodules at the beginning of flowering; N2- number of nodules at the end of flowering; PC -protein content; FC- fat content; P1-control, unfertilized, P2-fertilized with $50 \mathrm{~kg} / \mathrm{ha}$ P205; P3- fertilized with $100 \mathrm{~kg} / \mathrm{ha}$ P205; G1-control, unfertilized; G2-fertilized with 5 t/ha gulle; G3- fertilized with 10 t/ha gulle; G4- fertilized with 15 t/ha gulle.

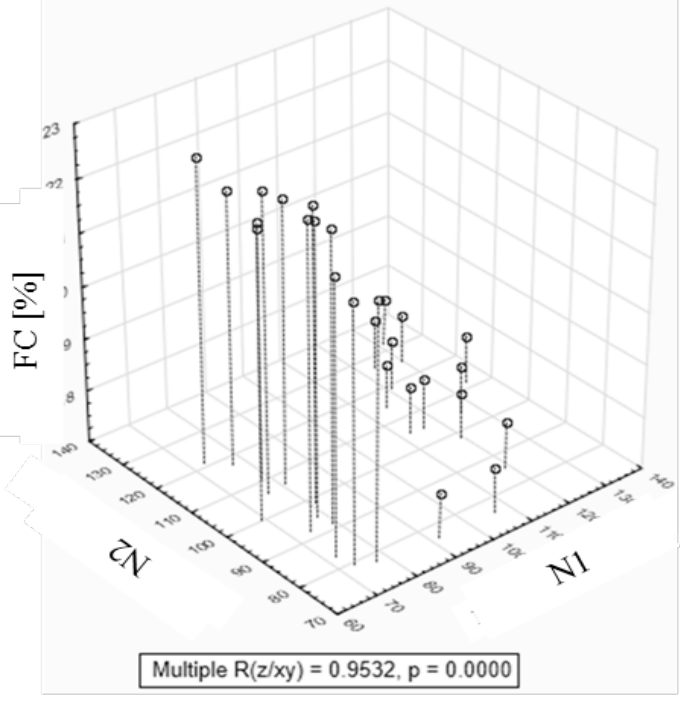

Fig. 3. Correlation between FC and N1, N2 (2013 and 2014)

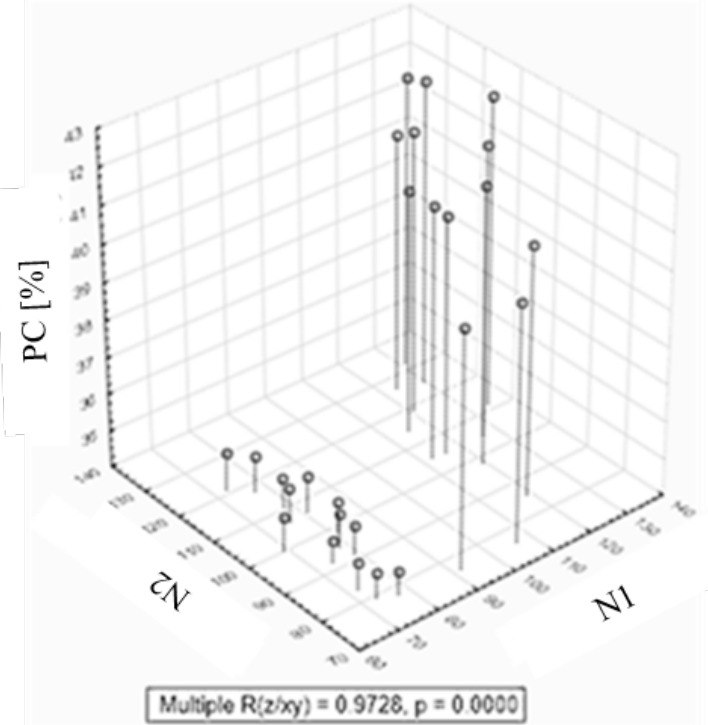

Fig. 4. Correlation between PC and N1, N2 (2013 and 2014)

Note: N1- number of nodules at the beginning of flowering; N2- number of nodules at the end of flowering; PC -protein content; FC- fat content. 


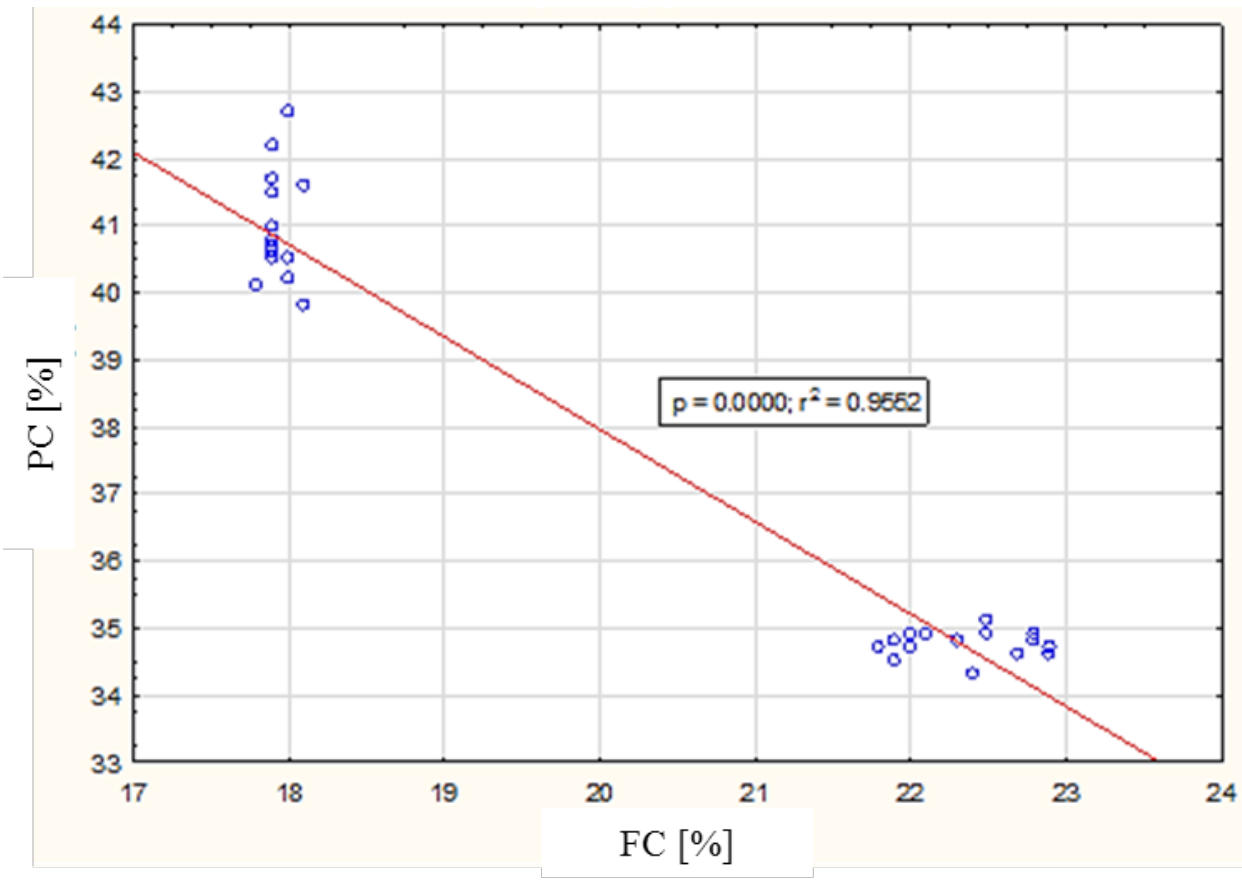

Fig. 5. Correlation between FC and PC on Felix genotype (2013 and 2014)

Note: N1- number of nodules at the beginning of flowering; N2-number of nodules at the end of flowering; PC -protein content; FC- fat content.

A positive correlation was observed between the number of nodules at the beginning and at the end of flowering and fat and protein content with highly signification from statistical point of view $\left(\mathrm{p}<0.001 ; \mathrm{r}^{2}=0,9532(\mathrm{FC})\right.$ and $\mathrm{r}^{2}=0.9728(\mathrm{PC})$ ) as shown in Fig. 3 and Fig. 4.

Analysing the results registered we observed that fat content is increasing once with the decreasing of protein content and vice versa, aspect highlighted by significant values of the regression coefficient $\mathrm{r} 2=0,9552$ (Fig. 5). Our results are confirmed by other researches in this regard which also concluded that the relationship between PC and FC is described thru a negative correlation (Hartwig and Kilen, 1991; Panthee et al., 2005; Wilcox and Guodong, 1997; Wilson, 2004; Yaklich et al., 2002).

\section{CONCLUSION}

The results showed an interesting evolution of Felix soybean breed under the influence of differentiated treatments. While mineral fertilization showed no significant influence on soybean fat and protein content interesting variation were highlighted on the experimental plot fertilized with gulle. Protein content was influenced by this treatment, the highest value being recorded on the experimental plot fertilized with $15 \mathrm{t} / \mathrm{ha}$ gulle. A positive correlation was observed between the number of nodules at the beginning and at the end of flowering and fat and protein content with highly signification from statistical point of view $\left(\mathrm{p}<0.001 ; \mathrm{r}^{2}=0.9532(\mathrm{FC})\right.$ and $r^{2}=0.9728(\mathrm{PC})$ ). A negative correlation was observed between fat content and protein content.

\section{REFERENCES}

1. Adu-Dapaah HK, Asafo-Adjei B, Owusu-Akyaw M, Amoah $S$ (2004). Sustainable Soybean Production in Ghana. Paper presented at a Radio program on soybean in Ghana 6 pages.

2. De Bruin J, Pederson P (2008). Yield improvement and Stability for Soybean Cultivars with Resistance to Heterodera Ichinohe. Agronomy Journal, 100 (5):13541359.

3. Dwevedi A, Kayastha A (2011). Soybean: a Multifaceted Legume with Enormous Economic Capabilities. SoybeanBiochemistry, Chemistry and Physiology, Prof. Tzi-Bun Ng (Ed.), 978-9-53307-219-7. In Tech, available on: http:// www.intechopen.com/books/soybean-biochemistrychemistry-and-physiology/soybean-a-multifacetedlegume-with-enormous-econ omic -capabilities .

4. Hartwig EE, Kilen TC (1991). Yield and composition of soybean seed from parents with different protein, similar yield. Crop Sci., 31:290-292. 
5. MoFA and CSIR (2005). Soybean Production Guide. Food crops development project. Ghana's Ministry of Food and Agriculture, 38.

6. Muntean LS, Cernea S, Morar G, Duda M, Vârban D, Muntean S (2011) Fitotehnie. Edit. Risoprint, ClujNapoca.

7. Panthee DR., Pantalone VR, West DR., Saxton AM., Sams CE (2005). Quantitative trait loci for seed protein and oil concentration, and seed size in soybean. Crop Sci., 45: 2015-2022.

8. Rotar I, Mărcuş (Deac) V, Vidican R, Mălinaș A (2015). Answer of a soybean genotype created on ARDS Turda to different fertilization. Bulletin of University of Agricultural Sciences and Veterinary Medicine ClujNapoca. Agriculture, 72 (2):55-59.
9. Wilcox JR., Guodong Z (1997). Relationships between seed yield and seed protein in determinate and indeterminate soybean populations. Crop Sci., 37: 361-364.

10. Wilson RF (2004). Seed composition. In: Soybeans: Improvement, production, and uses. $3^{\text {rd }}$ edition, H. R. Boerma, \& J. E. Specht, (Eds.), ASA Monogr. 16. ASA, Madison, WI, 621-669.

11. Yaklich RW, Vinyard B, Camp M, Douglass S (2002). Analysis of seed protein and oil from soybean Northern and Southern Region Uniform Tests. Crop Sci., 42:15041515. 